\title{
Evaluating the Kemplang Tunu Production Training for Low Income and Education Communities Using the Kirkpatrick Model
}

\author{
Terttiaavini, Luis Marnisah, Yosef Yulius, Tedy Setiawan Saputra* \\ Universitas Indo Global Mandiri \\ Palembang, Indonesia \\ *tdyfaith@gmail.com
}

\begin{abstract}
The research aims to measure the achievement of the training program for the Kemuning partnership in Ario Kemuning regent of Palembang city. The participants consisted of the housewife and teenagers who has low education and income background. The training which provides was based on social problems. The society needs training which could motivate them to become an entrepreneur. The measurement method was the Kirkpatrick model with 3 levels, they are reaction, learning, and behavior. Base on the weight calculation for each indicator value resulted in the score of each level as below, reaction, learning shows that The participant shows a positive reaction because they are wise to get something good during training activities and behavior is The participant shows a positive reaction because they are wise to get something good during training activities. The result shows that the training program has been accepted and implemented by the participants. Besides that, according to the understanding assessment with indicator scope on the product knowledge, staples and production process reached a good score. The training program was given an outcome for the society and so it could become a pilot project for a similar training program in another area.
\end{abstract} tunu

Keywords—training evaluation, Kirkpatrick's model, Kemplang

\section{INTRODUCTION}

The society prosperity improvement program already become a high priority to invent a prosperous society. The main social problems in some areas are different, therefore it should find the best solution. The problems handling has to consider the influence factors both from society side, cultural side and also the society needed.

Palembang city has an ethnic culture, such as art, tradition, handcraft, tourism destination and culinary. One of the traditional foods which most famous in Palembang city is Kemplang Tunu. People could find it easily in the traditional stores, on the narrow street and also on the intercity road. The price of kemplang tunu is very cheap, therefore it became a favorite meal for the people. Kemplang Tunu mostly produces by the home industry in the suburb and village in a traditional way and supported by classic tools. However, sometimes the production process of kemplang tunu is unhealthy. For example, the main staples to produce kemplang tunu is fish Sometimes, the people use the fishes which have died more than a day, so that it creates an unpleasant smell. Besides the production process is still classic, kemplang tunu is also sales in a traditional way. The people could find the kemplang tunu package just hang on the hanger at a small kiosk at the roadside. It is very dangerous for the seller and buyer since it could be caused by a traffic accident. On the financial side, the people who are as a producer and seller of kemplang tunu, does not have enough knowledge on how to calculate capital, cost, and profit, so that the gain was not maximum. Base on this condition, the author attempt to assist the traditional producer and seller to be a modern producer and seller of kemplang tunu [1].

The author was considered to hold training for them on how to produce a healthy kemplang tunu and how to grow and get more gain from their business. The author was presented as an experience and expert trainer, especially in the kemplang tunu production, marketing and financial. The solution which offered was held a training for partnership in Kemuning regent. The participants consisted of housewife and teenagers with a total of 20 participants. Most of them with low education and income (below standard). They needed training and motivation in order to increase their skill in the kemplang tunu production by independently. The training was consist of 4 aspects, they are 1) how to produce the kemplang tunu 2) how to create a simple book 3) brand image and packing shape 4) legality and trademark [1]. To make the training more valuable, the author has evaluated the training program by utilizing the Kirkpatrick Model.

Recently, the implementation of the Kirkpatrick model has been implemented on the various sector such as training program for the employee at universities [2,3], a training program for airlines crue [4], HR training \& Development [58]. Training for the hospital employe [9-16]. Evaluation of learning lets administrators assess and appreciate the effects of their financial investment in training and instructors and 
curriculum developers determine the efficacy of a program [7]. Related to the limited time and participants during the training, therefore the evaluation only until to level 3 , they are 1Reaction, 2-Learning, and 3-Behavior. The purpose of this training is to create a new start up that runs the kemplang tunu business. The results of this training resulted in three new stars running that business.

\section{LITERATURE REVIEW}

Kirkpatrick Model is able to use for any activities, depend on the needed [17]. Kirkpatrick is also able to use to evaluate any activities with measuring the ability participants before and after a training program. Usually, the Kirkpatrick model is applied to measure training activities carried out by employees in companies or institutions. but the current application can be implemented for various activities. Some activities which could be measured by using the Kirkpatrick model are:

- The effectiveness evaluation of the training for the employee, teacher and manager at Eslamshahr University. The result of the evaluation is good enough. However, it should be improved by making good planning from goal site, management commitment budget, individual purpose, job and organization [18].

- Training evaluation for Development Human Resource is a purpose to know the effectiveness of the training program for Human Resources with two assessments categorized, they are skill enhancement and behavioral changes. The categorized is an assessment of the planning, designing, and implementation. The evaluation result shows that the obstacles of the training effectiveness came from human resources development functions [8].

- The PIA training center evaluation. The training was the first time conducted. The evaluation result shows that the training program was effectively conducted on all of the levels. The training was useful for the employee. The employee hopes the training could be done anymore with a new subject and suitable to improve the skill since the mindset changes and the whole organization perspective [5].

- The capacity building for critical care training evaluation was purposed to assessed whether the training program was effective or not. The evaluation result there was an increase in all of the demonstrated. A good material presented could be increased by $25 \%$ increment skill simultaneously [9].

- Leadership and teacher training evaluations are purposeful to measure whether the participants have good leadership and teaching skill or not. The evaluation result shows than the participant has good achievement. It was correlated to the ability for prepared and presented the material properly, ability to give a study case and accomplishment, ability to build the trust and cooperation among office mate, ability to fixed the problems, ability to delegated the task, personality ability, a good communication, etc. [15]

The literature review result from other previous research could be concluded that the increment of the participant's ability could be achieved through by a good training planning, determined a training purpose to increase the performance/vision of the organization, commitment, and motivation of the participants to increase their skill, the supporting working environment, presenting the suit material, the optimum training time. Besides that, based on the assessment to be a leader, and so the leader has to able to create and deliver the material properly, ability to give a case study and accomplishment, ability to build the trust and cooperation among the office mate, ability to fixed the problems, ability to delegated the task, personality ability, a good communication, etc. Based on the activities carried out, the Kirkpatrick model will be used to measure the ability of the participants, the participant's assessment of the training provided and the feedback that participants get from the training.

Kirkpatrick model consisted of four-level, they are level 1 reaction, to assessed the participant reaction on the training program, level 2 learning, to assessed the lecture, level 4 behavior, to assessed the changes of the participants after attended the training program, level 4 result, to evaluated the whole training program and the impact to the organization [19].

The level reaction and learning categorized as a short-term evaluation, meanwhile the behavior and organization result as a long-term evaluation. Each level has a different assessment purpose; however, it has the same purpose. The process of the data collecting and result in each level are provides on the table 1 as below:

TABLE I. ACTIVITIES, COLLECTING DATA AND ASSESSMENT BY KIRKPATRICK MODEL

\begin{tabular}{|l|l|l|}
\hline $\begin{array}{c}\text { Level } \\
\text { Evaluation }\end{array}$ & \multicolumn{1}{|c|}{ Description } & \multicolumn{1}{c|}{ Method and Result } \\
\hline 1. Reaction & $\begin{array}{l}\text { To measure the participant's } \\
\text { satisfaction with the training } \\
\text { program. }\end{array}$ & $\begin{array}{l}\text { Questioner } \\
\text { Utilized the Likert scale } \\
\text { Result: Satisfied } \\
\text { unsatisfied }\end{array}$ \\
\hline 2. Learning & $\begin{array}{l}\text { To measure the knowledge } \\
\text { of the training material. }\end{array}$ & $\begin{array}{l}\text { Questioner } \\
\text { Utilized the Likert scale } \\
\text { Result: Understood / Not } \\
\text { Understood }\end{array}$ \\
\hline 3. Behavior & $\begin{array}{l}\text { To measure the ability of the } \\
\text { participants in the } \\
\text { implemented the training } \\
\text { result. }\end{array}$ & $\begin{array}{l}\text { Action plan } \\
\text { Direct assessment and } \\
\text { questioner } \\
\text { Result: Able / Disable }\end{array}$ \\
\hline 4. Result & $\begin{array}{l}\text { To measure the outcome } \\
\text { from the business side and } \\
\text { organization }\end{array}$ & $\begin{array}{l}\text { Evaluation of the action } \\
\text { plan and working result } \\
\text { report }\end{array}$ \\
\hline
\end{tabular}

Formula to calculate the weight each level provides as below:

Weight of level $\mathrm{N}=\frac{\text { Total Point of Respondent Answer }}{\text { Highest Point X Number of Respondent }}$ 
The results of the calculation of the level weights are interpreted in the Criteria table 2 and the valuation formula, given as follows:

TABLE II. CRITERIA OF ASSESSMENT VALUE

\begin{tabular}{|c|l|}
\hline \multicolumn{1}{|c|}{ Range } & \multicolumn{1}{c|}{ Interpretation } \\
\hline$<50 \%$ & $\begin{array}{l}\text { The participant shows a bad reaction to the } \\
\text { training activities }\end{array}$ \\
\hline $50 \%-60 \%$ & $\begin{array}{l}\text { The participant shows a good reaction to the } \\
\text { training activities }\end{array}$ \\
\hline $61 \%-80 \%$ & $\begin{array}{l}\text { The participant shows a positive reaction } \\
\text { because they are wise to get something good } \\
\text { during training activities }\end{array}$ \\
\hline $81 \%-100 \%$ & $\begin{array}{l}\text { The participant shows a high positive } \\
\text { reaction }\end{array}$ \\
\hline
\end{tabular}

Source: Data process by the researche

Each level has a different assessment result. The training achievement indicator could conclude more detail by utility Understanding of the Lean Principle concept. Base on the achievement result become a reference in order to develop the next training program.

\section{METHODS}

The research was utilized a qualitative descriptive approach, where the participant assessment base on their experiences during the training. The training was held for 1 month with the number of participants $=20$ participants. The remaining partnership consisted of housewives and teenagers with an educational background at primary, junior and senior high school degrees.

The approbation speed of the participant was a contradiction if compared to the participants with the education background at the university degree. The training material consisted of (1) training how to produce the kemplang tunu (2) training how to make a simple book (3) socialization the impact of the brand image and create a packing shape (4) socialization how to proposed the legality and trademark [1]. The training evaluation was utilized the Kirkpatrick model with 3 levels, they are reaction, learning, and behavior. The data was collected from the distributed questioner to the participants at each level. The activities at each level are explained as follows:
Level 1 - Reaction: Measuring on level 1 was focus on the participant's satisfaction with the training program. Therefore, at the end of the training, the participants were given a questioner list which has to answer, the questions in the questioner list consisted of the training facilities (module, sound system, supporting things, meal and infrastructure) and also the lecture process.

Level 2 - Learning: On level 2, the measuring was focus on the participant knowledge. In this passage, the trainer gave two tests to all of the participants. There are pre-test and post-test. All of the questions in the questioner list were about the participant's knowledge of the product, production process, working capital management, and profit.

Level 3 - behavior: Measuring on level 3 was focus on how the participant implemented their knowledge as their behavior in their working environment. Related to this matter, after training complete, the trainer has circulated the questioner to the participants for assessed their training mate behavior. The questions in the questioner list consisted of how their training mate understanding the training materials and how they implemented it in the environment.

\section{RESULTS AND DISCUSSION}

\section{A. Results}

Base on the Kirkpatrick formula, the summary of the answered questionnaire for each level, provides on table 3 , as below:

TABLE III. CRITERIA OF ASSESSMENT VALUE

\begin{tabular}{|l|c|c|c|l|}
\hline \multicolumn{1}{|c|}{$\begin{array}{c}\text { Levels of } \\
\text { Kirkpatrick } \\
\text { model }\end{array}$} & \multicolumn{3}{|c|}{ Participant } & \multirow{2}{*}{ Criteria Point } \\
\cline { 2 - 5 } & $\boldsymbol{n}$ & $\begin{array}{c}\text { Pre- } \\
\text { test }\end{array}$ & $\begin{array}{c}\text { Post- } \\
\text { test }\end{array}$ & \\
\hline $\begin{array}{l}\text { Level 1: } \\
\text { Reaction }\end{array}$ & 20 & $84.00 \%$ & none & $\begin{array}{l}\text { The participant shows a } \\
\text { high positive reaction }\end{array}$ \\
\hline $\begin{array}{l}\text { Level 2: } \\
\text { Learning }\end{array}$ & 20 & $54.29 \%$ & $68.33 \%$ & $\begin{array}{l}\text { The participant shows a } \\
\text { positive reaction } \\
\text { because they are wise to } \\
\text { get something good } \\
\text { during training activities }\end{array}$ \\
\hline $\begin{array}{l}\text { Level 3: } \\
\text { Behavior }\end{array}$ & 20 & $85.19 \%$ & none & $\begin{array}{l}\text { The participant shows a } \\
\text { high positive reaction }\end{array}$ \\
\hline
\end{tabular}

During the training, particularly on the level 2, the participants were assessed before and after training. To measure the level of understanding, the scores were classified according to a pre-defined criterion. The average scores achieved by participants and the classification are shown on table 5 below: 
TABLE IV. UNDERSTANDING BY LEAN PRINCIPLE

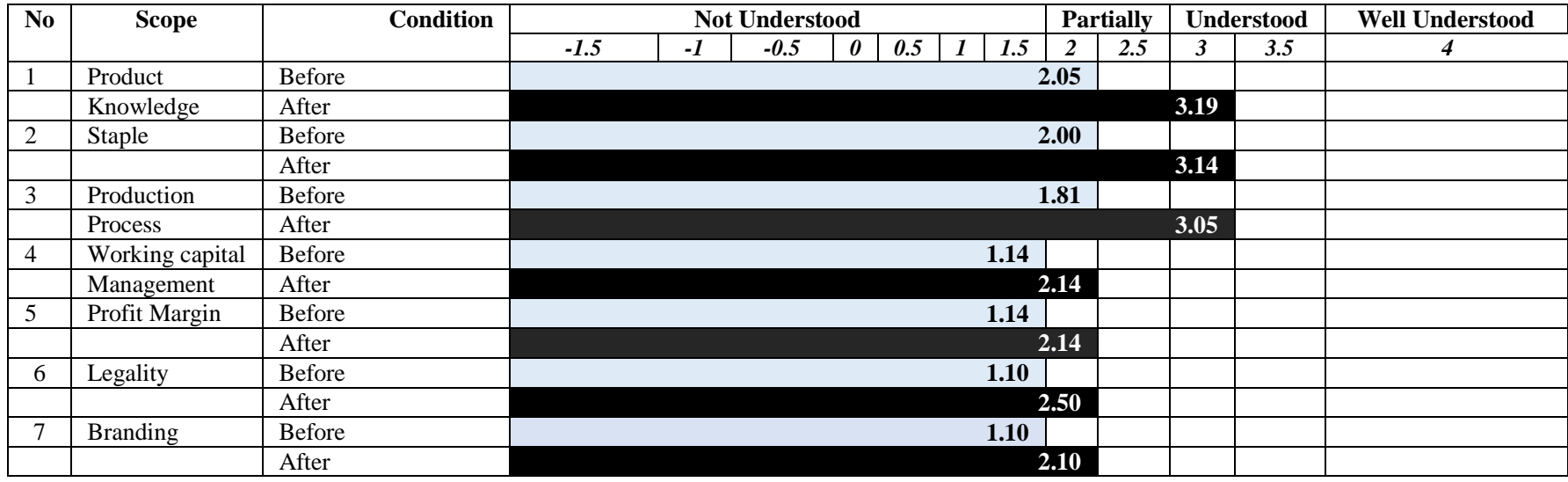

An objective of this research was to determine how well the Lean principles were understood after training. The results are shown in Figure 1.

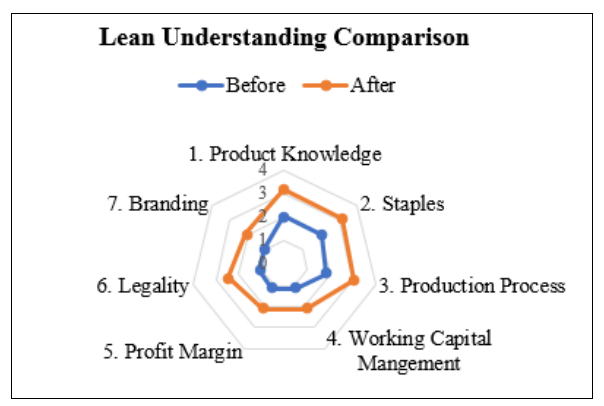

Fig. 1. Comparison Level 2: Learning between post-test and test.

\section{B. Discussion}

The table 3 shows that on level 1, the participant felt satisfied with the training which has been conducted. It does mean that all of the components of the training have full fill the participant expectation, such as training module, the environment of training and instructor. On level 2, shows that there is an increase of the participant knowledge on how to produce a healthy product, how to sell the product, how to calculate the capital, how to calculate the cost of goods sold and how to calculate the profit margin properly.

Base on table 4, the understanding of the participant to the training materials had been an increase from partially understood to be understood. There are has a significant score increased between $53,66 \%$ for staple scope and $90,91 \%$ for legality and branding scope.

The graph chart in figure 1 shows that the point after training has been increasing compared to before training. It does mean, the participant's knowledge getting better than before.

Generally, level 3 shows the information that the participant able to applicate the training result on the community. In another word, the participant ready to run the business both individually and together (small group).

\section{CONCLUSION}

The training conducted on the Kemuning partnership has a success suit to the purpose and goal. The key success of the training is a high motivation from the participants, the right training, the instructor who has good skills in the delivery training material and also the readiness of the staples to process the product. The Kirkpatrick model produces an assessment of the implementation of the training, for a more detailed analysis, one can use other assessment methods such as Understanding of lean principles before and after training.

We would like to thank the Director-General of Ristekdikti and Universitas Indo Globa Mandiri for fully funding Community Services for 2019 and also for the Kemuning partners who have worked together to conduct training programs.

\section{REFERENCES}

[1] T. Terttiaavini, L. Marnisah, Y. Yulius, and T.S. Saputra, "Pengembangan Kewirausahaan "Kemplang Tunu" Sebagai Produk Cemilan Khas Kota Palembang," Jurnal Abdimas Mandiri, vol. 3, no. 1, 2019.

[2] S. Farjad, "The Evaluation Effectiveness of Training Courses in University by Kirkpatrick Model (Case Study: Islamshahr University)". Procedia - Soc Behav Sci., vol. 46, pp. 2837-2841, 2012.

[3] R.B. Gunderman and S. Chan, "Kirkpatrick's Evaluation of Educational Programs and its Relevance to Academic Radiology," Acad Radiol, vol. 22, pp. 1323-1325, 2015.

[4] T. Yongliang, L. Hu and Y. Jiao, "Evaluation of simulation-based training for aircraft carrier marshalling with learning cubic and Kirkpatrick's models," Chinese J Aeronaut, vol. 28, pp. 152-163, 2015.

[5] M. Rafiq, "Training Evaluation in an Organization using Kirkpatrick Model : A Case Study of PIA," Eur J Bus Manag, vol. 7, pp. 152-162, 2015.

[6] A. Smidt, S. Balandin and J. Sigafoos, "The Kirkpatrick model: A useful tool for evaluating training outcomes," J Intellect Dev Disabil, vol. 34, pp. 266-274, 2009. 
[7] S. Makumbe, T. Hattingh, and N. Plint, "Effectiveness of using Learning Factories to impart Lean principles in mining employees," Procedia Manuf, vol. 23, pp. 69-74, 2018.

[8] S.A. AlYahya, "Evaluation Of Effectiveness Of Training And Development: The Kirkpatrick Model," Asian J Bus Manag Sci. vol. 2, pp. 14-24, 2012.

[9] T. Stephens, A.P. De Silva, and A. Beane, "Capacity building for critical care training delivery: Development and evaluation of the Network for Improving Critical care Skills Training (NICST) programme in Sri Lanka," Intensive Crit Care Nurs, pp. 1-9, 2016.

[10] K.A. Moreau, "Has the new Kirkpatrick generation built a better hammer for our evaluation toolbox?" Med Teach., vol. 39, pp. 9991001, 2017.

[11] C.F. Mackenzie, S.A. Tisherman, and S. Shackelford, "Efficacy of Trauma Surgery Technical Skills Training Courses," J Surg Educ., vol. 76, pp. 832-843, 2019.

[12] R. Avraham, V. Shor, and N. Hurvitz, "Transferability of medication administration simulation training to clinical settings," Teach Learn Nurs, vol. 13, pp. 258-262, 2018.

[13] M. Bijani, K. Rostami, and M. Momennasab, "Evaluating the Effectiveness of a Continuing Education Program for Prevention of
Occupational Exposure to Needle Stick Injuries in Nursing Staff Based on Kirkpatrick's Model," J Natl Med Assoc, vol. 110, pp. 459-463, 2018.

[14] S.E. Buriak, and C.L. Ayars, "Evaluation of a drug and alcohol safety education program in aviation using interrupted time series and the Kirkpatrick framework," Eval Program Plann., vol. 73, pp. 62-70, 2019.

[15] M. Colella, M. Bisanzo, and C. Farquhar, "Implementation and evaluation of an innovative leadership and teacher training program for non-physician emergency medicine practitioners in Uganda," African J Emerg Med, vol. 9, pp. 25-29. 2019.

[16] T. Cox, N. Seymour, and D. Stefanidis, "Moving the Needle: Simulation's Impact on Patient Outcomes," Surg Clin North Am., vol. 95, pp. 827-838, 2015.

[17] M. Bucur, "A Study on Business Communication on Corporate Social Responsibility in Romania," Procedia Technol., vol. 19, pp. 996-1003, 2015.

[18] F. Shahrooz, "The Evaluation Effectiveness of training courses in University by Kirkpatrick Model (case study: Islamshahr university)," Procedia - Soc Behav Sci., vol. 46, pp. 2837-2841, 2012.

[19] D.L. Kirkpatrick and J.D. Kirkpatrick, Evaluating training programs: The four levels. Third. San Francisco: Berrett-Koehler, 2009. 